\title{
RANCANGAN SISTEM INFORMASI PENJUALAN PADA TOKO KUE
}

\author{
Angelina Permatasari \\ Program Information System Audit, School of Information System, BINUS University \\ Jl.KH.Syahdan no.9 Kemanggisan Palmerah Jakarta Indonesia \\ angelina_psw@binus.ac.id
}

\begin{abstract}
The purpose of this research is to analyze the problems that may occur in the cake stores, especially the selling system used in the store, identify information needs and designing suitable sales information systems for the store. The methodology used in this research are analysis and design methods. Analysis methods that used in this research are study literature, observation, survey of the old system, analysis of survey needs, identification of information needs and interview. While the design method that used in this research is Object Oriented Analysis and Design (OOAD). The results achieved is sales information system for cake store in the form of application design to replace the manual system. Conclusion, a computerized sales information system can improve existing sales procedures and solve the problems that may occur in the old system
\end{abstract}

Keywords: design, sales information system, Object Oriented Analysis and Design (OOAD)

\begin{abstract}
ABSTRAK
Tujuan penelitian ini adalah untuk menganalisis masalah-masalah yang ada pada toko kue yaitu mengenai sistem penjualan yang sedang berjalan pada toko tersebut, mengidentifikasi kebutuhan informasi toko dan merancang sistem informasi penjualan yang mampu menjawab kebutuhan informasi tersebut. Metodologi yang digunakan adalah metode analisis dan metode perancangan. Metode analisis yang dilakukan pada penelitian ini adalah studi pustaka, teknik observasi, survei terhadap sistem lama, analisis kebutuhan survei, identifikasi kebutuhan informasi, dan wawancara. Sedangkan metode perancangan yang digunakan adalah Object Oriented Analysis and Design (OOAD). Hasil yang dicapai adalah berupa sistem informasi penjualan bagi toko kue dalam bentuk perancangan aplikasi untuk menangani sistem penjualan yang selama ini masih dilakukan secara manual. Sistem informasi penjualan yang terkomputerisasi dapat memperbaiki prosedur penjualan yang sudah ada dan mengatasi masalah-masalah yang timbul pada system penjualan yang lama.
\end{abstract}

Kata kunci: perancangan, sistem informasi penjualan, Object Oriented Analysis and Design (OOAD) 


\section{PENDAHULUAN}

Untuk memulai sebuah usaha tidaklah selalu membutuhkan modal yang besar. Dengan kreatifitas dan ketekunan, hobi, keterampilan atau bakat dapat dijadikan bisnis yang menguntungkan. Di dalam dunia entrepreneurship ada satu pedoman bahwa untuk memulai bisnis tidak selalu dibutuhkan modal yang besar. Akan tetapi kerja keras, ketekunan dan keseriusan itulah modal yang dapat membuat sebuah usaha terus berkembang.

Memasuki tahun 2012, industri makanan dan minuman diprediksikan masih akan terus bersinar meramaikan persaingan pasar. Menurut data yang diperoleh dari GAPMMI (Gabungan Pengusaha Makanan dan Minuman Indonesia), volume penjualan bisnis makanan dan minuman dalam negeri terus mengalami peningkatan yang cukup tajam. Bahkan menurut hasil pencatatan data dari Departemen Perindustrian dan Perdagangan, sekarang ini sektor makanan, minuman, dan tembakau memberikan kontribusi paling besar yakni sekitar 34,45\% terhadap pertumbuhan industri nasional.

Studi kasus penelitian ini adalah toko yang bergerak dalam bidang penjualan kue. Dalam menjalankan rutinitasnya, toko ini masih menggunakan sistem manual sehingga sering menimbulkan masalah antara lain kesalahan dalam perhitungan penjualan, ketidakakuratan dalam perhitungan stok, kurangnya integritas data dan kurangnya pengawasan terhadap karyawan dan lain-lain. Menurut Berisha (2011), keberadaan sistem informasi di dalam dunia bisnis dan manajemen adalah untuk melayani aneka ragam kebutuhan sehingga perlu diberikan lebih banyak perhatian pada teknologi sistem informasi karena teknologi tersebut merupakan kunci untuk manajemen yang lebih baik dan keberhasilan di dalam bisnis.

Oleh karena itu, ruang lingkup yang akan dibahas pada penelitian ini meliputi perancangan sistem informasi penjualan pada toko kue yang meliputi beberapa hal seperti perhitungan penjualan, perhitungan stok, informasi stok minimum, laporan omzet penjualan per periode, laporan piutang yang dalam perancangan sistem informasi ini menggunakan database Ms.Access 2007 dan program Borland Delphi versi 5. Tujuan dari penelitian ini adalah mengidentifikasi sejauh mana sistem informasi penjualan dapat bermanfaat bagi toko, menganalisis masalah yang ada pada sistem yang sedang berjalan dan merancang sistem informasi penjualan yang sesuai dengan kebutuhan toko kue tersebut.

Manfaat dari penelitian ini adalah dapat mengetahui kekurangan dan kelemahan yang ada pada sistem yang sedang berjalan sehingga dapat diatasi dan mampu menghindarkan kesalahan dalam perhitungan ataupun kesalahan dalam penyajian laporan. Selain itu dapat memberikan informasi yang benar dan tepat waktu kepada pihak manajemen sehingga dapat menunjang pengambilan keputusan yang terbaik dan penelitian ini dapat berguna bagi toko kue dalam meningkatkan efektifitas dan efisiensi dalam siklus penjualan.

\section{METODE}

Metode yang digunakan adalah sebagai berikut. Pertama, metode analisis yaitu studi pustaka, teknik observasi, survey terhadap sistem lama, analisis kebutuhan, identifikasi kebutuhan informasi, wawancara. Kedua, metode perancangan adalah menggunakan Object Oriented Analysis and Design $(O O A D)$ yang dimulai dengan pembuatan rich picture, event table, entity relationship diagram, use case diagram, rancangan database, rancangan layar, rancangan laporan. 


\section{Teori Pendukung}

Sistem informasi adalah suatu pengelolaan yang berarti mengumpulkan, memasukkan, mengolah data dan menyimpan, mengelola data, mengendalikan data dan pelaporan informasi sehingga organisasi dapat mencapai tujuan dan sasaran (O’Brien, 2006). Sistem Informasi Akuntansi (SIA) adalah sebuah sistem yang mengumpulkan, mencatat, menyimpan, dan memproses data untuk menghasilkan informasi bagi pembuat keputusan. Marshall, Rommney dan Paul Steinbart. (2006)

UML adalah sebuah software bahasa pemodelan untuk spesifikasi, visualisasi, kontruksi, dan dokumentasi suatu sistem informasi (Jones dan Rama, 2006). Pengertian database adalah kumpulan dari tabel-tabel. Satu tabel merepresentasikan suatu entitas tertentu dan suatu entitas terdiri atas beberapa atribut. Salah satu manfaat database adalah untuk memudahkan dalam mengakses data. Kemudahan pengaksesan data ini adalah sebagai implikasi dari keteraturan data yang merupakan syarat mutlak dari suatu database yang baik. (Haryanto, 2004)

Object-Oriented Analysis and Design adalah sekumpulan petunjuk umum untuk membuat analisis dan desain (Mathiassen, 2000) Use case diagram adalah suatu daftar use case yang terdapat dalam suatu aplikasi dan yang mengindikasikan actor yang bertanggung jawab terhadap masingmasing use case (Jones dan Rama, 2006) Database Relasional adalah suatu database yang di dalamnya terdapat tabel-tabel yang saling berelasi satu sama lain (Haryanto, 2004).

Entity Relationship Diagram atau Diagram Hubungan Antar Entitas merupakan hasil akhir dari proses analisis terhadap sistem yang ditinjau yang dilakukan oleh seorang Analis Sistem. (Haryanto, 2004) Sistem pengendalian internal adalah meliputi struktur organisasi, metode, dan ukuran-ukuran yang dikoordinasi untuk menjaga kekayaan perusahaan, mengecek ketelitian, dan kehandalan data akuntansi, mendorong efisiensi dan dipatuhinya kebijakkan manajemen (Mulyadi, 2001). Penjualan adalah jumlah yang dibebankan kepada pelanggan untuk barang dagangan yang dijual, baik secara tunai maupun kredit (Warren, 2005). Layar (interface) adalah bagian dari batasan antara dua sistem yang berinteraksi berseberangan yang saling berkomunikasi (Bennett, 2006). Laporan adalah data yang ditampilkan secara terformat dan terorganisasi (Jones dan Rama, 2006)

\section{HASIL DAN PEMBAHASAN}

\section{Sistem Penjualan yang Sedang Berjalan}

Sistem penjualan pada toko kue ini masih dilakukan secara manual. Karyawan yang terlibat ada 10 orang yang terdiri dari kasir, staf pengadaan barang, koki, dan manajer. Proses bisnisnya adalah pelanggan melakukan pemesanan kue kepada kasir. Pelanggan membayar transaksi tersebut dan kasir mencetak struk penjualan. Untuk pelanggan tertentu, kasir memperbolehkan untuk pembayaran kemudian (kredit). Bila pembayaran secara kredit, pelanggan dapat melakukan pembayaran keesokan harinya atau beberapa hari kemudian. Pada saat penutupan atau pergantian shift, kasir memberikan pertanggungjawaban kepada manajer.

Analisis temuan survei menunjukkan: (1) Pencatatan penjualan masih dilakukan secara manual sehingga seringkali terjadi kesalahan dalam perhitungan penjualan. (2) Ketidakakuratan dalam perhitungan stok kue yang ada sehingga terkadang ada stok yang habis atau belum siap pada saat pelanggan memesan. (3) Tidak adanya pengawasan terhadap stok kue (Rentan terhadap kecurangan karyawan). (4) Pemilik seringkali terlambat dalam menerima Laporan setiap periode. (5) Ada fasilitas yang diberikan kepada pelanggan tertentu yaitu fasilitas pembayaran kemudian (kredit) namun belum ada pencatatan khusus untuk hal tersebut. 
Pengidentifikasian Kebutuhan Informasi meliputi: (1) Informasi Penjualan setiap Periode. (2) Informasi Stok Minimum. (3) Kartu Stok Kue. (4) Laporan Omset Penjualan. (5) Laporan Piutang.

\section{Rich Picture Prosedur Penjualan}

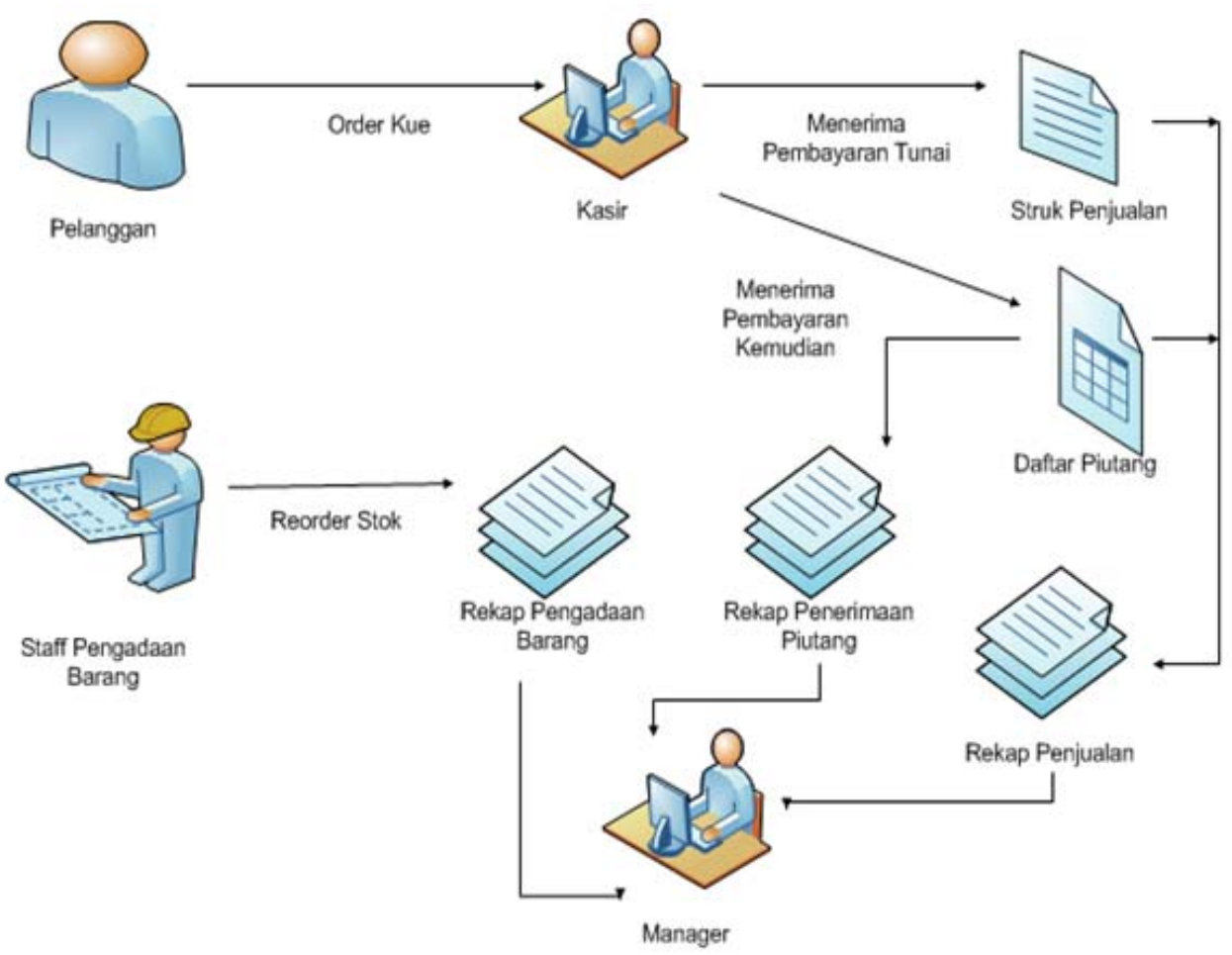

Gambar 1 Rich Picture Prosedur Penjualan yang Diusulkan

\section{Keterangan:}

- Pelanggan memesan kue yang diinginkan kepada kasir.

- Jika pelanggan membayar tunai, kasir mencetak Struk Penjualan. Akan tetapi kalau pelanggan membayar kemudian (kredit), informasi tersebut akan dimasukkan ke dalam Daftar Piutang.

- Staff Pengadaan Barang mengecek stok kue yang ada. Jika Stok sudah mendekati minimum (atau ada reminder dari sistem), staff pengadaan barang akan meminta koki untuk langsung membuat kue jenis tersebut.

- Pada saat penutupan atau saat pergantian kasir, kasir mempertanggungjawabkan jumlah kas yang diterima dan manajer dapat mencetak Rekap Penjualan, Rekap Pengadaan Barang dan Rekap Penerimaan Piutang setiap periode yang diinginkan. 


\section{Perancangan Sistem}

Tabel 1 Event Table Sistem Informasi Penjualan yang Diusulkan

\begin{tabular}{|c|c|c|c|}
\hline Event & $\begin{array}{l}\text { Internal Agent } \\
\text { Assuming } \\
\text { Responsibility }\end{array}$ & Starts When & Activities in the event \\
\hline $\begin{array}{l}\text { Melakukan pencatatan } \\
\text { penjualan }\end{array}$ & Kasir & Pelanggan memesan kue & $\begin{array}{l}\text { Menerima pembayaran dan } \\
\text { meng-entry penjualan ke } \\
\text { komputer, mencetak struk } \\
\text { penjualan }\end{array}$ \\
\hline Mengecek Stok & $\begin{array}{l}\text { Staff Pengadaan } \\
\text { Barang }\end{array}$ & $\begin{array}{l}\text { Pada saat stok mencapai } \\
\text { minimum atau ada reminder } \\
\text { dari sistem }\end{array}$ & $\begin{array}{l}\text { Mengecek kartu stok kue dan } \\
\text { meminta koki untuk membuat } \\
\text { kue }\end{array}$ \\
\hline $\begin{array}{l}\text { Menerima pembayaran } \\
\text { piutang }\end{array}$ & Kasir & $\begin{array}{l}\text { Pelanggan melakukan } \\
\text { pembayaran piutang }\end{array}$ & $\begin{array}{l}\text { Mencatat ke dalam Daftar } \\
\text { Piutang }\end{array}$ \\
\hline $\begin{array}{l}\text { Melaporkan Hasil } \\
\text { Penjualan }\end{array}$ & Kasir & $\begin{array}{l}\text { Pada saat pergantian shift atau } \\
\text { penutupan }\end{array}$ & $\begin{array}{l}\text { Menyetorkan seluruh hasil } \\
\text { penjualan ke Manajer }\end{array}$ \\
\hline $\begin{array}{l}\text { Menerima hasil } \\
\text { penjualan }\end{array}$ & Manager & $\begin{array}{l}\text { Menerima hasil penjualan dari } \\
\text { kasir }\end{array}$ & $\begin{array}{l}\text { Memeriksa hasil penjualan } \\
\text { yang diterima, mencetak } \\
\text { Laporan-Laporan }\end{array}$ \\
\hline
\end{tabular}




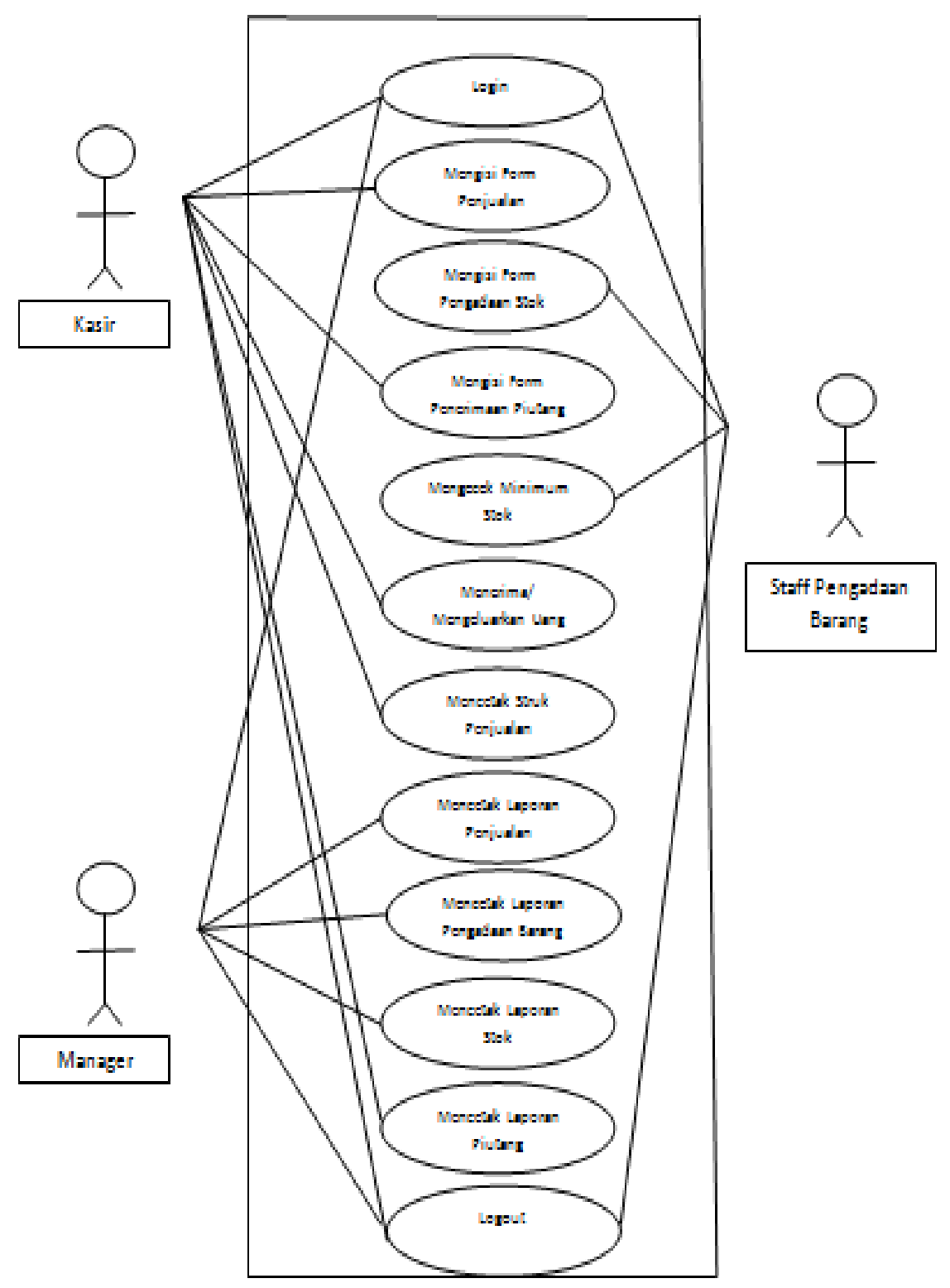

Gambar 2 Use Case Diagram Sistem Informasi Penjualan yang Diusulkan 


\section{Rancangan Database}

Tabel 2 Kue

\begin{tabular}{lccl}
\hline \multicolumn{1}{c}{ Field Name } & Data Type & Field Size & \multicolumn{1}{c}{ Description } \\
\hline KodeKue & text & 5 & Primary Key untuk Tabel Kue \\
KodeJenis & text & 5 & FK Tabel Kue \\
HargaReseller & number & double & Harga untuk Jual kembali \\
HargaCustomer & number & double & Harga untuk Customer \\
Qty & number & integer & Stok Kue \\
SaldoMinimum & number & integer & Saldo Minimum Kue \\
\hline
\end{tabular}

Tabel 3 Jenis

\begin{tabular}{lccl}
\hline \multicolumn{1}{c}{ Field Name } & Data Type & Field Size & \multicolumn{1}{c}{ Description } \\
\hline KodeJenis & text & 5 & PK untuk Tabel Jenis \\
Nama & text & 50 & Nama jenis kue \\
\hline
\end{tabular}

Tabel 4 Customer

\begin{tabular}{lccl}
\hline \multicolumn{1}{c}{ Field Name } & Data Type & Field Size & \\
\hline KodeCustomer & text & 5 & Description \\
Nama & text & 20 & Nama \\
Alamat & text & 30 & Alamat \\
Kota & text & 20 & Kota \\
Telepon & text & 20 & Telepon \\
HP & text & 20 & Nomor HP \\
\hline
\end{tabular}

Tabel 5 Supplier

\begin{tabular}{cccl}
\hline Field Name & Data Type & Field Size & \\
\hline KodeSupplier & text & 5 & Description \\
Nama & text & 20 & Nama \\
Alamat & text & 30 & Alamat \\
Kota & text & 20 & Kota \\
Telepon & text & 20 & Telepon \\
HP & text & 20 & Nomor HP \\
\hline
\end{tabular}

Tabel 6 Header Pengadaan Barang

\begin{tabular}{lccl}
\hline \multicolumn{1}{c}{ Field Name } & Data Type & Field Size & \\
\hline NoFaktur & text & 20 & PKescription \\
KodeSupplier & text & 5 & FK tabel Pengadaan Barang \\
Subtotal & number & double & Subtotal \\
Diskon & number & double & Diskon \\
Total & number & double & Total \\
Bayar & number & double & Bayar \\
Sisa & number & double & Sisa \\
\hline
\end{tabular}


Tabel 7 Detail Pengadaan Barang

\begin{tabular}{lccl}
\hline \multicolumn{1}{c}{ Field Name } & Data Type & Field Size & \multicolumn{1}{c}{ Description } \\
\hline NoFaktur & text & 20 & FK untuk Detail Pengadaan Barang \\
KodeKue & text & 5 & FK tabel Pengadaan Barang \\
Qty & number & double & Qty \\
Hsatuan & number & double & Hsatuan \\
Total & number & double & Total \\
\hline
\end{tabular}

Tabel 8 Header Penjualan

\begin{tabular}{lccl}
\multicolumn{1}{c}{ Field Name } & Data Type & Field Size & \\
\hline NoFaktur & text & 20 & Description \\
KodeCustomer & text & 5 & FK tabel Penjualan \\
Subtotal & number & double & Subtotal \\
Diskon & number & double & Diskon \\
Total & number & double & Total \\
Bayar & number & double & Bayar \\
Sisa & number & double & Sisa \\
\hline
\end{tabular}

Tabel 9 Detail Penjualan

\begin{tabular}{lccl}
\multicolumn{1}{c}{ Field Name } & Data Type & Field Size & \multicolumn{1}{c}{ Description } \\
\hline NoFaktur & text & 20 & FK untuk Detail Penjualan \\
KodeKue & text & 5 & FK tabel Penjualan \\
Qty & number & double & Qty \\
Hsatuan & number & double & Hsatuan \\
Total & number & double & Total \\
\hline
\end{tabular}




\section{Rancangan Layar}

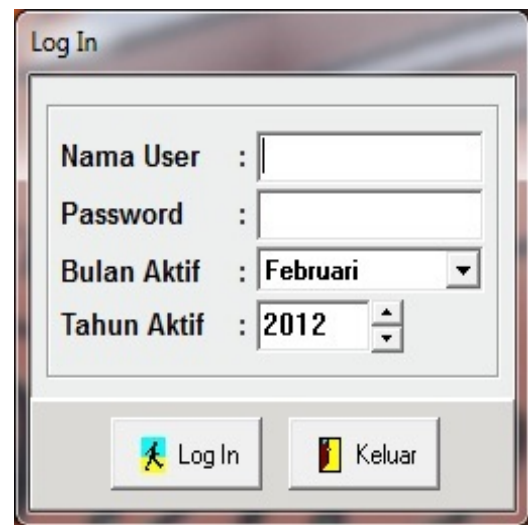

Gambar 3 Layar Login

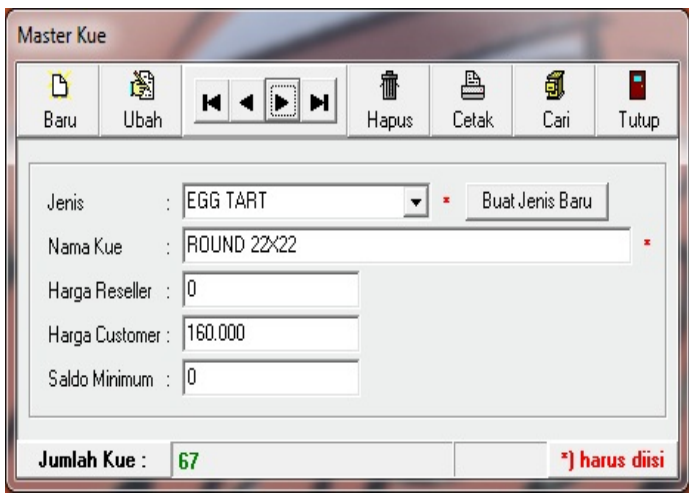

Gambar 4 Master Kue

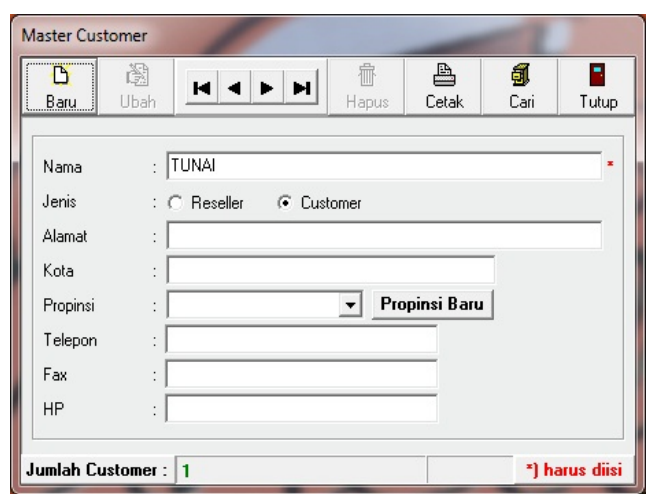

Gambar 5 Master Customer

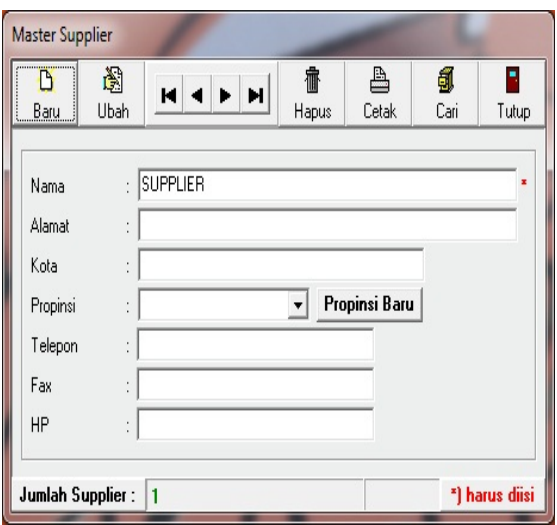

Gambar 6 Master Supplier

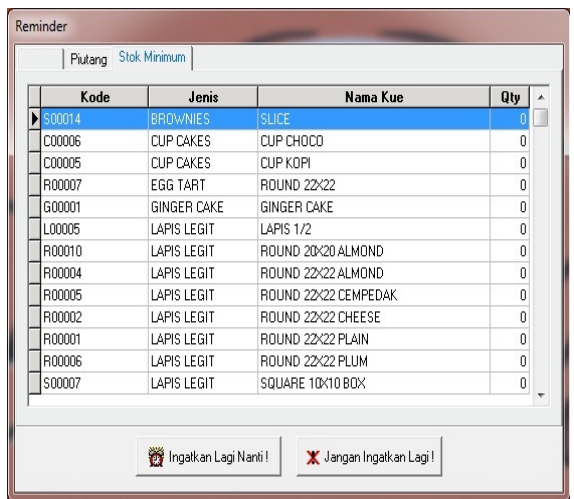

Gambar 7 Reminder Stok

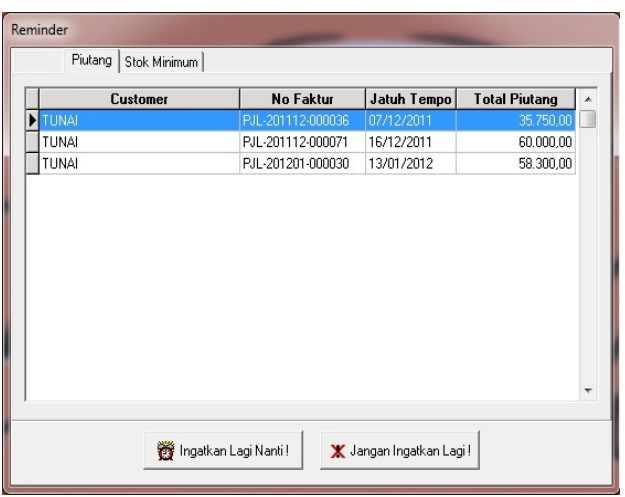

Gambar 8 Reminder Piutang 


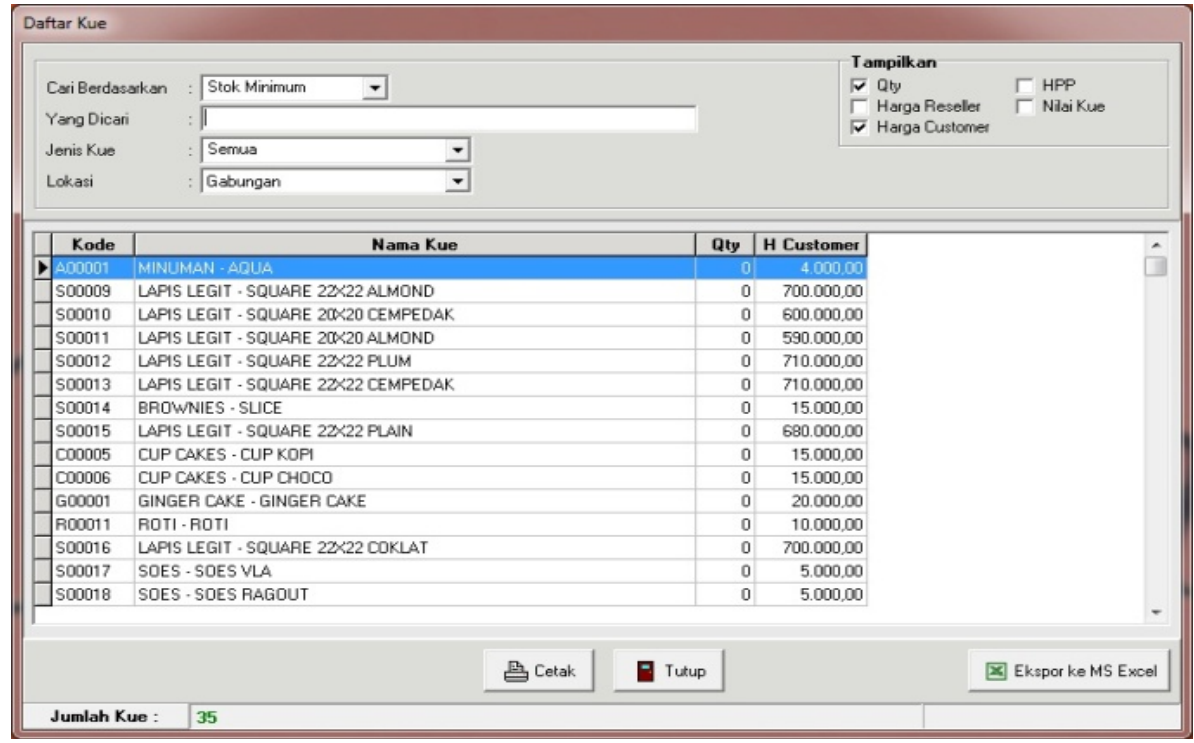

Gambar 9 Daftar Kue

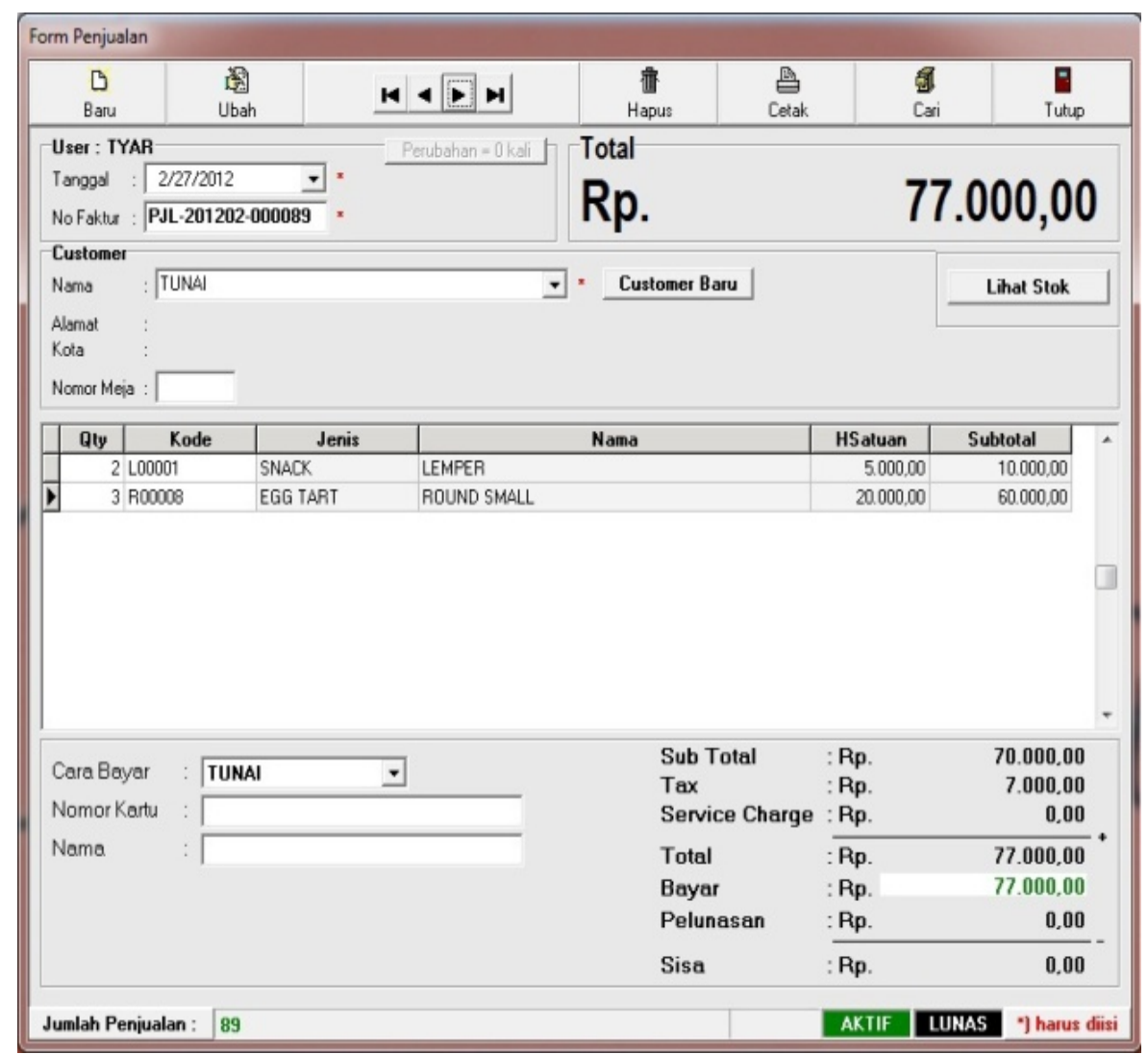

Gambar 10 Form Penjualan 


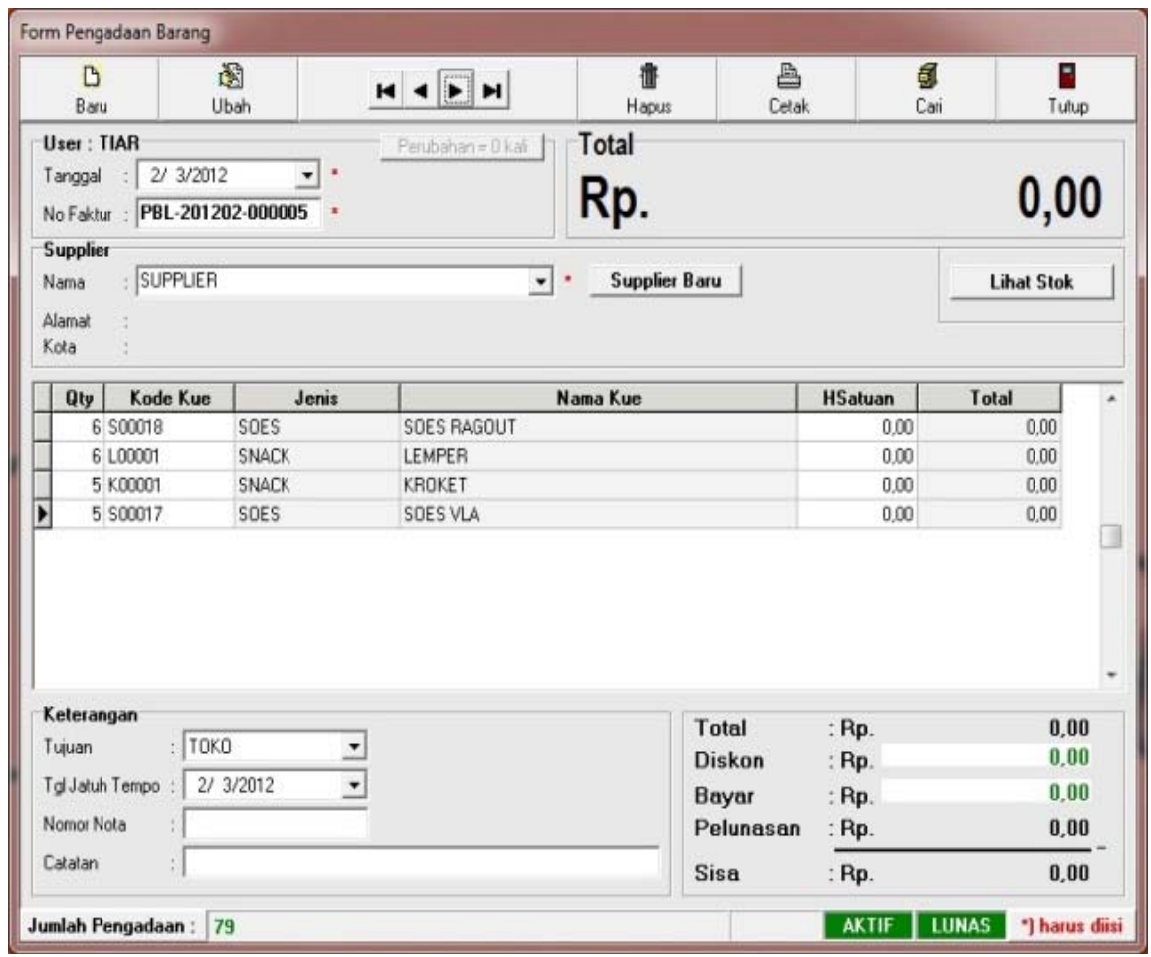

Gambar 11 Form Pengadaan Barang

Dicetak Tgl : 29/02/2012 10:48:22 PM Oleh : ADMIN

LAPORAN PENJUALAN

Periode : Februari 2012

\begin{tabular}{|c|c|c|c|c|}
\hline No. No. Faktur & Tgl Faktur Customer & \multicolumn{3}{|c|}{ Nilai Transaksi } \\
\hline 1. PJl-201202-000001 & 01/02/2012 TUNAI & Rp. & $33.000,00$ & TUNAI \\
\hline 2. PJL-201202-000002 & 01/02/2012 TUNAI & Rp. & $44.000,00$ & TUNAI \\
\hline 3. PJL-201202-000003 & 0202/2012 TUNAI & Rp. & $91,300,00$ & TNVPIU \\
\hline 4. PJL-201202-000004 & 0202/2012 TUNAI & Rp. & $44.000,00$ & TNVPIU \\
\hline 5. PJL-201202-000005 & 03/02/2012 TUNAI & Rp. & $148.500,00$ & TNVPIU \\
\hline 6. PJl-201202-000006 & 03/02/2012 TUNAI & Rp. & $5.500,00$ & TUNAI \\
\hline 7. PJL-201202-000007 & 0302/2012 TUNAI & Rp. & $148.500,00$ & TNVPIU \\
\hline 8. PJL-201202-000008 & 04/02/2012 TUNAI & Rp. & $88.000,00$ & TUNAI \\
\hline 9. PJl-201202-000009 & 05/02/2012 TUNAI & Rp. & $5.500,00$ & TUNAI \\
\hline 10. PJL-201202-000010 & 05/02/2012 TUNAI & Rp. & $115.500,00$ & TNVPIU \\
\hline 11. PJL-201202-000011 & 06/02/2012 TUNAI & Rp. & $66.000,00$ & TNVPIU \\
\hline 12. PJL-201202-000012 & 0602/2012 TUNAI & $R p$. & $5.500,00$ & TUNAI \\
\hline 13. PJL-201202-000013 & 07/02/2012 TUNAI & Rp. & $33.000,00$ & TUNAI \\
\hline 14. PJL-201202-000014 & 07/02/2012 TUNAI & Rp. & $5.500,00$ & TNVPIU \\
\hline 15. PJl-201202-000015 & 07/02/2012 TUNAI & Rp. & $51.700,00$ & TUNAI \\
\hline
\end{tabular}

Gambar 12 Form Penjualan 


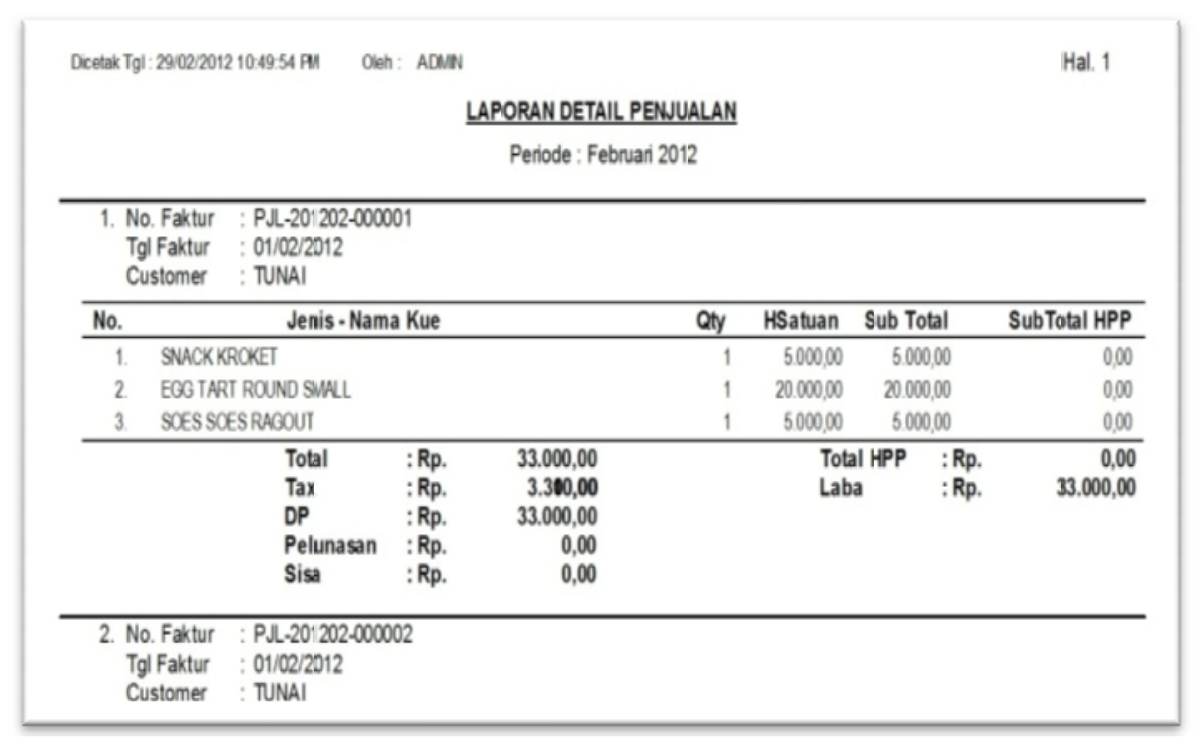

Gambar 13 Laporan Detail Penjualan

\section{SIMPULAN}

Berdasarkan pembahasan yang dipaparkan sebelumnya dan hasil analisis dan perancangan sistem informasi penjualan maka dapat disimpulkan bahwa pencatatan terhadap transaksi penjualan masih dilakukan secara manual. Toko tidak menggunakan sistem aplikasi yang terkomputerisasi maka dirancang sebuah sebuah sistem informasi yang berbasis komputer yang dapat mengatasi kelemahankelemahan tersebut, sehingga sistem informasi penjualan yang ada menjadi lebih efektif dan efisien.

Sistem informasi penjualan yang dirancang dapat mengatasi masalah human error dalam penghitungan penjulan dan stok dan dapat menghasilkan informasi penjualan yang akurat dalam bentuk Laporan Omset Penjualan, Informasi Stok Kue dan Stok Minimum, Laporan Piutang bagi pihak manajemen. Pembatasan hak akses dilakukan untuk menghindari pihak-pihak yang tidak berwenang untuk dapat mengakses data.

Saran yang dapat diberikan adalah dilakukan pelatihan terhadap karyawan yang akan menangani sistem informasi penjualan. Back up data harus dilakukan secara berkala untuk menjaga histori informasi agar dapat digunakan sebagaimana mestinya.

\section{DAFTAR PUSTAKA}

Bennett, S., Mcrobb, S., Farner, R. (2006). Object-oriented system analysis and design using UML. New York: Mc Graw-Hill, inc.

Berisha, N. M. (2011). Information Systems Usage in Business and Mangement. International Journal of Innovation in the Digital Economy: 12-23.

Haryanto, I. (2004). Membuat database dengan Microsoft Office Access. Bandung: Informatika. 
Jones, F. L., Rama, D. V. (2006). Accounting Information System: A business Process Approach. Canada: Thompson South Westren.

Mathiassen, L., Madsen, A. M., Nielsen, P. A., Stage, J. (2000). Object Oriented Analysis \& Design. (Edisi 1). Denmark: Forlaget Marko.

Marshall B. R., Steinbart, P. J. (2006). Accounting Information System. (International edition, tenth edition). USA: Pearsih education, Inc.

Mulyadi. (2001). Sistem Akuntansi. (Edisi 3). Jakarta: Salemba Empat.

O’Brien, J., Marakas, A., George, M. (2006). Management Information System. (seventh edition). New York: McGraw-Hill.

Warren, C. S., Reeve, J. M., Fess, P. E. (2005). Accounting. (Twenty-First Edition). South-Western. 